\title{
Urgensi Pemikiran Syams Al-Aimmah Al-Syarakhsi Tentang Al-Istihsan Dalam Menjawab Problematika Hukum Dalam Masyarakat
}

\author{
Syawaluddin Hanafi \\ Faculty of Sharia, Institut Agama Islam Negeri Bone, \\ Sulawesi Selatan, \\ Jl. HOS. Cokroaminoto, Kabupaten Bone, \\ Sulawesi Selatan, Indonesia. \\ Email: syawaluddin.hanafi@@gmail.com
}

\begin{abstract}
This research try to raise the perspective of Islamic law answering the problems in society by using the Al-Istihsan method of Syams Al-Aimmah Al-Syarakhsi. The complexity of the existing regulations has not been able to answer the problems in society, so we need a way to find the law. This research is a qualitative research with a conceptual approach with data collection methods obtained through the work of Syams Al-Aimmah Al-Syarakhsi and literature that discusses about Istihsan.

The results of this study found that; First, Istihsan can be used as a argument for syariah because istihsan does not stipulate law with analogy, istihsan is a method of legal istinbath that can be accounted for because it is based on a strong foundation (sanad); Second, after describing istihsan in ushul fiqih in the view of the Hanafi school, it can be said that in essence istihsan is one of the efforts of the mujtahid to find a way out of the power of general principles or qiyas to aparticular problem in order to find legal provisions that are more in accordance with The soul and spirit of the Shariah, because indeed the texts cannot be understood only in language but also understood by using the broad logic of making shari'a (Al-Mantiq Al-tasyri'i) which gives the mujtahid the opportunity to realize the will of Al Shariah.
\end{abstract}

Keywords: Al-Syarakhsi, Istihsan, Law, Society.

Abstrak: Penelitian ini bertujuan untuk mengangkat perspektif hukum Islam dalam menjawab masalah-masalah yang muncul di tengah masyarakat dengan menggunakan pemikiran Syams Al-Aimmah Al-Syarakhsi tentang Al-Istihsan. Kompleksitas regulasi 
yang ada ternyata belum mampu menjawab problematika ditengah masyarakat sehingga dibutuhkan cara untuk menemukan hukumnya. Penilitian ini merupakan penelitian kualitatif dengan pendekatan konseptual dengan metode pengumpulan data yang diperoleh melalui karya Syams Al-Aimmah Al-Syarakhsi dan literatur yang membahas tentang Istihsan.

Hasil penelitian ini menemukan bahwa; Pertama, Istihsan dapat di jadikan sebagai dalil syara' karena istihsan itu bukan menetapkan hukum dengan ra'yi semata, istihsan itu merupakan suatu cara istinbath hukum yang dapat di pertanggung jawabkan karena di dasarkan kepada sandaran (sanad) yang kuat; Kedua, Setelah diuraikan istihsan dalam ushul fiqih dalam pandangan madzhab Hanafi maka dapat dikatakan bahwa pada hakikatnya istihsan itu merupakan salah satu upaya mujtahid untuk mencari jalan keluar dari kekuatan kaidah umum atau qiyas terhadap suatu masalah juz'i dalam rangka mencari ketentuan hukum yang lebih sesuai dengan jiwa dan ruh syari'at, karena memang nash tidak bisa di pahami hanya secara bahasa semata tetapi harus di pahami dengan menggunakan logika pembuatan syariat (AlMantiq Al-tasyri'i) yang luas yang memberikan kesempatan kepada mujtahid untuk merealisasikan kehendak Al syari'semaksimal mungkin.

Keywords: Al-Syarakhsi, Istihsan, Hukum, Masyarakat.

\section{Pendahuluan}

Ketergantungan manusia terhadap norma hukum sangatlah besar dan urgen untuk menata kehidupan antara individu dengan individu lainnya, kelompok manusia dengan kelompok manusia lainnya. Realitas hubungan diantaranya kemudian menimbulkan persoalan yang mengakibatkan disharmoni terhadap tatanan kehidupan, sebab ada orang/kelompok yang diuntungkan disisi lain dan ada pihak yang dirugikan. Kemudian hukum hadir memberikan pengetahuan tentang tuntunan kehidupan yang belum dipahami mekanisme menyelesaikan permasalahan dan menjalani kehidupan yang harmonis sehingga dipahami makna dan indahnya kehidupan itu.

Pada dasarnya hukum hadir memberikan pembagian yang sama antara orang/kelompok dengan kelompok lainnya, dalam artian tidak dibedakan antara yang satu dan yang lainnya, baik itu miskin atau kaya, hitam atau putih kulitnya, laki-laki ataupun perempuan, semua diatur dalam ketentuan yang sama kecuali hal-hal tertentu yang diatur meringankan atau lebih memudahkan. 
Namun teori itu tidak sejalan dengan realitasnya, sebab hampir setiap waktu ditemukan adanya kelompok tertentu yang selalu menjastifikasi kelompok masyarakat yang lain. Saat suatu perilaku tertentu dilakukan maka dianggap sesat dan tidak sesuai dengan anjuran agama (Al-Qur'an dan Sunnah Nabi). Seperti dalam beberapa kegiatan dalam pesta perkawinan di Indonesia, kelompok ini dengan mudahnya melontarkan kata "Bid'ah", mereka beralasan bahwa apa yang dilakukan dalam kegiatan perkawinan adalah Nabi Muhammad Saw. tidak pernah melakukannya, sementara sebagai ummat Islam harus mencontoh apa yang dilakukan oleh Nabi. Adapun Hadits yang diselalu diungkapkannya adalah:

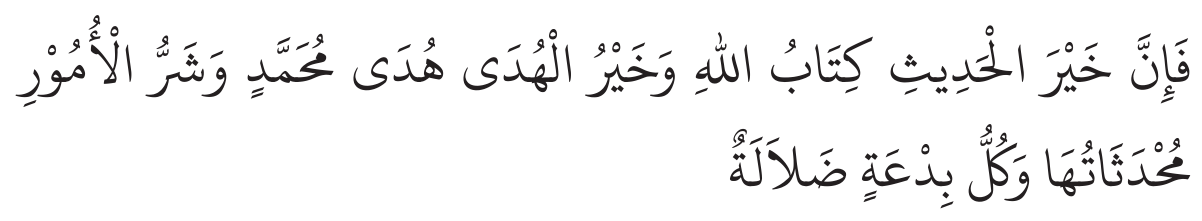

Artinya: "Sesungguhnya sebaik-baik perkataan adalah kitabullah dan sebaik-baik petunjuk adalah petunjuk Muhammad shallallahu 'alaihi wa sallam. Sejelek-jelek perkara adalah (perkara agama) yang diada-adakan, setiap (perkara agama) yang diada-adakan itu adalah bid'ah, setiap bid'ah adalah kesesatan" (HR. Muslim no. 867).

Di sisi lain diajarkan bahwa Islam adalah agama yang hadir untuk semeseta alam (universal). Universalisme (al->Alamiyah) Islam adalah salah satu karakteristik Islam yang agung. Islam sebagai agama yang besar berkarakteristikkan: (1) Rabbaniyyah, (2) Insaniyyah (humanistik), (3) Syumul (totalitas) yang mencakup unsur keabadian, universalisme dan menyentuh semua aspek manusia (ruh, akal, hati dan badan), (4) Wasathiyah (moderat dan seimbang), (5) Waqiiiyah (realitas), (6) Jelas dan gamblang, (7) Integrasi antara al-Tsabat wa al-Murunah (permanen dan elastis). ${ }^{1}$

Universalisme Islam yang dimaksud adalah bahwa risalah Islam ditujukan untuk semua umat, segenap ras dan bangsa serta untuk semua

${ }^{1}$ https://media.isnet.org/kmi/islam/gapai/Akulturasi.html, diakses pada 13 September 2020. 
lapisan masyarakat. Ia bukan risalah untuk bangsa tertentu yang beranggapan bahwa dia-lah bangsa yang terpilih, dan karenanya semua manusia harus tunduk kepadanya. Risalah Islam adalah hidayah Allah untuk segenap manusia dan rahmat-Nya untuk semua hamba-Nya. Manifestasi ini termaktub dalam firman Allah SWT Surah Al-A'raf ayat 158 bahwa:

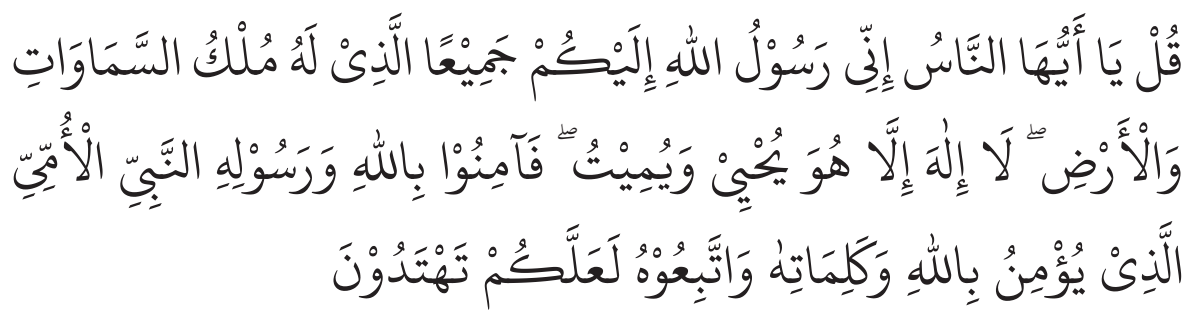

Artinya: "Dan tidak Kami utus engkau (Muhammad) kecuali sebagai rahmah bagi seluruh alam». "Katakanlah (Muhammad) agar ia menjadi juru peringatan bagi seru sekalian alam". 2

Ayat di atas adalah ayat Makkiyah, secara implisit membantah tuduhan sebagian orientalis yang menyatakan bahwa Muhammad Saw tidak memproklamirkan pengutusan dirinya untuk seluruh umat manusia pada awal kerisalahannya, akan tetapi setelah mendapat kemenangan atas bangsa Arab. ${ }^{3}$

Universalisme Islam menampakkan diri dalam berbagai manifestasi penting, dan yang terbaik adalah dalam ajaran-ajarannya. ${ }^{4}$ Ajaran-ajaran Islam yang mencakup aspek akidah, syari' ah dan akhlak (yang sering kali disempitkan oleh sebagian masyarakat menjadi hanya kesusilaan dan sikap hidup), menampakkan perhatiannya yang sangat besar terhadap persoalan utama kemanusiaan. Hal ini dapat dilihat dari enam tujuan umum syari'ah yaitu; menjamin keselamatan agama, badan, akal, keturunan, harta dan kehormatan. Selain itu risalah Islam juga menampilkan nilai-nilai kemasyarakatan (social values) yang luhur, yang

${ }^{2}$ QS. Al-A'raf: 158.

3 Yusuf Al-Qardhawi, Al-khashaish Al-'Aamiyah al-Islam, (Beirut-Libanon; cet. VIII, 1993)., hlm. 107-108.

${ }^{4}$ Abdurrahman Wahid, Universalisme Islam dan Kosmopolitanisme Peradaban Islam, dalam "Kontekstualisasi Doktrin Islam dalam Sejarah". Editor: Budhy Munawwar Rahman, (Jakarta: Yayasan Paramadina, cet. I, Mei 1994)., hlm. 515. 
bisa di katakan sebagai tujuan dasar syari'ah yaitu; keadilan, ukhuwwah, takaful, kebebasan dan kehormatan. ${ }^{5}$

Dalam Islam, Allah SWT melalui hukum/ syari'atnya mempunyai tujuan mulia untuk diimplementasikan dalam kehidupan ummat manusia, dan perlu diketahui bahwa Allah SWT sebagai syari' (yang menetapkan syari'at) tidak menciptakan hukum dan aturan begitu saja melainkan diciptakan dengan tujuan dan maksud tertentu. Oleh karena itu, syariat memiliki 'illat hukum yang dapat dipahami sekaligus kemaslahatan bagi manusia. Dan keterlibatan ahli hukum Islam (ulama) menjadi penting untuk berperan dalam berijtihad memberikan solusi terhadap permasalahan yang dihadapi ummat. Ijtihad untuk kemaslahatan ini merupakan kesepakatan ulama kecuali sebahagian kecil ulama dari ulama yang tekstual (ahli dzahir) memahami makna syari'at dan para pengikutnya. ${ }^{6}$

Ilmu Ushul Fiqh adalah salah satu ilmu perangkat dasar yang wajib dimiliki dan dikuasai oleh ahli hukum Islam yang berkehendak melaksanakanan istinbat hukum Islam, mencoba memahami maksud dan tujuan Allah Swt. yang terdapat dalam al-Qur'an dan RasulNya, baik yang berkaitan dengan masalah aqidah, muamalah, 'uqubah, maupun akhlak. ${ }^{7}$ Al-Gazali melukiskan ilmu ushul fiqh sebagai sebuah pohon yang ditanam oleh manusia. Buah-buahan pohon tersebut menggambarkan hukum-hukum yang merupakan tujuan dibalik menanam pohon; batang dan cabang-cabangnya adalah materi tekstual yang memungkinkan pohon menopang dan menahannya. Namun agar pohon tersebut bisa ditanam, dan menjadikan menopang buahnya, manusia harus berperan. Jadi unsur tambahan dalam gambaran metafora di atas adalah cara menanam, prinsip-prinsip penalaran hukum, dan hermeneutika, yang dipakai agar pohon tersebut bisa berbuah, dan yang terakhir adalah

5 Yusuf Al-Qardhawi, Madkhal li al-Dirasat al-Islamiyah, (Beirut-Libanon, cet. I,1993)., hlm. 61.

${ }^{6}$ Yusuf Al-Qardhawy, Pengantar Kajian Islam; Studi Analitik Komprehensif tentang Pilar-pilar Subtansi, Karakteristik, Tujuan, dan Sumber Acuan Islam, (Jakarta: Pustaka Al-Kausar, 1999)., hlm. 138.

7 Rachmat Syafe'i, Ilmu Ushul Fiqh untuk UIN, STAIN, PTAIS, (Bandung: Pustaka Setia, 2010)., hlm. 24. 
manusia itu sendiri yang tanpanya pohon tidak akan menghasilkan tujuan keberadaannya. $^{8}$

Perdebatan Ushul Fiqh (metodologi hukum islam) sangatlah kompleks dan dinamis. Masing-masing madzhab memiliki metodologi yang berbeda yang akhirnya berujung pada perbedaan hasil ijtihad mereka. Belakangan ini banyak orang yang seenaknya mengeluarkan fatwa. Parahnya lagi fatwa itu mereka keluarkan hanya untuk menyerang pihak lain. Mereka yang berani berfatwa tanpa menguasai ilmu Ushul alFiqh ada baiknya merenung apa sudah siap terkena ancaman Rasulullah SAW: "Orang yang paling berani di antara kalian dalam berfatwa adalah orang yang paling berani masuk neraka" (HR. Ad-Darimi).

Dalam pembahasan tentang syarat-syarat mujtahid, adalah penguasaan atas ilmu ushul fiqh menjadi syarat penting dan utama yang dikemukakan oleh para alim ulama. Hal ini bertujuan agar mekanisme dan proses ijtihad serta hasilnya bisa dipertanggung-jawabkan secara ilmiah. Meskipun para ulama sepakat atas hal tersebut, pada kenyataannya adalah tetap saja terjadi perbedaan-perbedaan pandangan di antara para mujtahid dalam penetapan hukum Islam sehingga ditemukan beragam madzhab dalam hukum Islam. ${ }^{9}$ Keragaman dalam perbedaan ini dipengaruhi oleh banyak faktor, salah satunya disebabkan adanya perbedaan dalam konsep ushul fiqh yang digunakan diantara para mujtahid. Pembahasan tentang dalil-dalil penetapan hukum Islam misalnya, ushul fiqh membagi dalil menjadi dua bagian kelompok besar, yakni dalil-dalil yang disepakati (al-Adillah al-Muttafaq 'Alaiha) dan dalil-dalil yang diperselisihkan (al-Adillah al-Mukhtlaf Fiha).

Berdasar pada teori tentang tata urutan secara hierarkis sumber hukum Islam adalah al-Qur'an kemudian As-Sunnah yang menjadi

${ }^{8}$ Abu Hamid Muhammad bin Muhammad Al-Gazali, Mustasyfa min 'Ilm al Ushul, (Cairo, al-Matba'a al-Amiriyya, 1906)., hlm. 8-9.

${ }^{9}$ Menurut Syatibi, Jelas bahwa seorang mujtahid pun bisa saja salah dalam melakukan kesalahan dalam mengahadapi sebuah kasus. Yang dikhawatirkan oleh Syatibi adalah mereka yang belum memiliki cukup persyaratan untuk berijtihad, dan orang-orang yang secara sembarangan berlaku tanpa pengakuan yang sah dari ahli fiqh yang diiuktinya, seolah telah layak menjadi mujtahid. Lihat uraian pandangan Syatibi dalam Wael B. Hallaq, Sejarah Teori Hukum Islam; Pengantar untuk Ushul Fiqh Mazhab Sunni, (Jakarta: Rajawali Pers, 2001)., hlm. 279. 
2 (dua) sumber pokok (masadir) hukum Islam. Hasil pemikiran dan pendapat para ulama kemudian menjadi sumber hukum berikutnya. Pendapat yang disepakati oleh semua/mayoritas ulama (ijma) tentu lebih tinggi nilai dan kemungkinan akan kedudukannya sehingga menjadi sumber yang ketiga. Sedangkan yang bersifat metode khusus yang menganalogikan apa yang terdapat dalam nash (sumber) dengan masalah yang tidak tercantum dalam nash tetapi memiliki krakteristik yang sama (al-qiyas) menjadi sumber keempat.

Beberapa sumber utama yang disebutkan di atas, ada seperangkat dalil hukum yang bersifat melengkapi dan keberadaannya menjadi perdebatan dikalangan ulama dan keberadaannya hanya disepakati oleh sebagian ulama yaitu diantaranya adalah Al-Istihsan. Kontroversi atas beberapa persoalan, yang banyak mengalirkan tinta dari pena para teoretisi dianggap oleh sebagian faqih hanya perselisihan verbal. ${ }^{10}$ Dalildalil yang disepakati adalah al-Qur'an, as-Sunnah, Ijma' dan Qiyas. Sementara dalil yang diperselisihkan diantaranya adalah Qaul Sahabi, Maslahah Mursalah, Istishab, Istihsan, dan sebagainya. Salah satu dalil yang diperselisihkan oleh ulama yang akan menjadi pembahasan dalam makalah ini adalah soal Istihsan. Istihsan dalam Karya Ushul fiqh Syams al-Aimmah Sarakhsi, salah seorang ulama dari mazhab hanafi yang dikenal sebagai pemuka mazhab Hanafi yang notabene bukan saja alim dalam bidang metodologi akan tetapi juga penulis dengan karya 30 jilid kitab fiqh yang berjudul al-Mabsut. Sarakhsi banyak menghabiskan waktunya dipenjara selama 15 tahun lamanya, itu disebabkan mengkritik Khalifah yang berkuasa pada saat itu, dan dengan memorinya yang luar biasa mendiktekan isi kitab al-Mabsut selama menjadi tahanan penguasa dibalik jeruji besi.

Tulisan ini akan menguraikan tentang istihsan, beberapa asumsi yang akan digunakan dalam pembahasan. Yaitu:

1. Istihsan diposisikan oleh Syarakhsi sebagai salah satu bentuk ijtihad.

${ }^{10}$ Aron Zysow, The Economy of Certainty: An Introduction to the Typology of Islamic Legal Theory, (United State, Disertasi Ph.D. Harvard University, 1984)., hlm. 403-404., lihat juga dalam Wael B. Hallaq, Sejarah Teori Hukum Islam; Pengantar untuk Ushul Fiqh Mazhab Sunni, (Jakarta: Rajawali Pers, 2001)., hlm. 163. 
2. Istihsan sebagai sumber atau dasar keputusan hukum.

3. Nilai argumentasi istihsan sebagai sumber hukum.

4. Penerapan istihsan dalam proses menemukan hukum.

Agar dalam pembahasan ini dapat dipahami, maka sistematika dibuat sebagai berikut: Pertama, akan diuraikan sejarah kemunculan istihsan dalam perbincangan hukum Islam. pembahasan ini menitiktekankan pada aspek faktor, ide-ide yang mendahului, dan kondisi yang membidani lahirnya gagasan mengenai istihsan. Kedua, konsepsi istihsan dalam bentuknya yang mutakhir dan keragaman modelnya merupakan pembahasan yang tidak boleh penulis lewatkan. Ketiga, konsepsi dan keragaman model yang diuraikan sebelumnya kemudian diperdebatkan kedudukannya sebagai sumber hukum Islam. Hal ini disebabkan para ulama senantiasa mendiskusikan kedudukan istihsan.

\section{Pembahasan}

\section{A. Biografi Syams Al Aimmah Sarakhsi}

Nama lengkap al-Sarakhsi adalah Abu Bakar Muhammad bin Ahmad bin Abi Sahl al-Sarakhsi, ${ }^{11}$ dalam hal ini belum dijelaskan secara pasti sejarah kelahirannya. ${ }^{12}$ Ia adalah ahli fikih, ushul fikih, teologi, dan hadis. Ia salah seorang pemikir/ulama Mazhab Hanaf ${ }^{13}$ dan berada pada peringkat ketiga dalam jajaran ulama pengikut Mazhab Hanafi. peringkat pertama: Imam Abu Yusuf dan Imam Muhammad bin Hasan al-Syaibani: peringkat kedua: Imam Abu Hasan Ubaidillah bin Hasan al-Karkhi). Walaupun al-Sarakhsi termasuk kategori ulama besar, riwayat hidupnya tidak ditemukan secara lengkap. Ia diketahui lahir di Sarakhs (Sarkhas), daerah Khurasan (Iran Timur laut), tanggal dan tahun kelahirannya tidak

\footnotetext{
${ }^{11}$ Kata al Sarakhsi, di baca fathah sin dan ra' nya dan mensukun kha', Sarakhsi, ada pula yang membaca fathah sin, mensukun ra' nya dan membaca fathah kha' nya, Sarkhasi. Lihat dalam Ahmad bin Abi Sahl al

Sarakhsi, Tarjamah al Mu'allif Ushul al Sarakhsi, (Beirut-Libanon: Dar al Kutub al Ilmiyah, juz 1, 1993, hlm. 4.

${ }^{12}$ Abdullah Musthafa al Maragi, Pakar-Pakar Fiqh Sepanjang Sejarah, (Yogyakarta: LKPSM, 2001)., hlm. 162.

${ }^{13}$ Muhammad bin Ahmad bin Abi Sahl al Sarakhsi, Tarjamah al Mu'allif al Mabsuth, juz 31, (Beirut-Libanon: Dar al Kutub al Ilmiah, 1993)., hlm. 7.
} 
tercatat di dalam banyaknya buku- buku biografi ulama fikih dan ushul fikih. Pada masa remaja al-Sarakhsi belajar ilmu fikih pada Abdul Aziz bin Ahmad al- Hulwani (w. 448 H/1056 M), seorang ahli fikih mazhab Hanafi yang bergelar Syams al-Aimmah (matahari para imam). Setelah belajar pada al-Hulawni, al-Sarakhsi mengalami perkembangan pesat dalam berbagai bidang ilmu, terutama ilmu fikih dan menjadi populer. Al-Sarakhsi terkenal dengan kepandaiannya. Daya ingatannya yang luar biasa terlihat ketika ia mendektikan isi bukunya, al- Mabsuth, sebuah buku fikih yang besar 15 jilid dan standar dalam Madzhab Hanafi. Ketika buku tersebut diterbitkan pada tahun 1409 H/1989 M oleh penerbit Dar al-Ma"rifah Beirut, Syekh Kholil al-Mais, seorang ulama Libanon menyusun satu jilid indeks untuk kelengkapan buku tesebut. Karyakarya Al-Sarakhsi mencakup bidang fiqh dan ushul fiqh. Karya dalam ilmu fikih di antaranya al-Mabsuth. Karya yang kedua adalah syarh Kitab al-Siyar al-Kabir, sebuah buku fikih yang berisi penjelasan atau komentar terhadap kitab al-Siyar al-Kabir karya Muhammad ibn Hasan al-Syaibani. Karya yang lain adalah syarh Mukhtashar al-Thahawi berisi penjelasan tehadap buku ringkasan yang dikarang oleh Imam Abu Ja'far Ahmad bin Muhammad al-Thahawi (w. 321 H/933 M; seorang tokoh ulama fikih Mazhab Hanafi). Termasuk karya al-Sarakhsi dalam bidang ilmu ushul fikih adalah Ushul al- Sarakhsi. Dalam buku ini al-Sarakhsi mengawali pembahasan dengan membicarakan masalah perintah dan larangan (al- amar wa al-nahy), karena menurut al-Sarakhsi bahwa persoalan perintah dan larangan merupakan dua hal yang utama dalam kajian ushul fikih.

\section{B. Al-Istihsan sebagai Metode Istinbath Hukum}

Hukum Islam sejak awal diterapkan hingga berkembang dan eksis hingga sekarang tentu sangat menarik untuk diteliti, digali, serta dikaji tak terkecuali bagi kalangan akademisi. Melihat sejarahnya para ulama biasanya menyelesaikan persoalan yang tidak ditemukan solusinya dalam Alquran maupun hadis dengan menggunakan metode istinbath hukum. hukum Islam yang disepakati oleh jumhur ulama hanya meliputi Alquran dan sunnah, sedangkan di luar dari itu terdapat metode dalam mengistinbatkan hukum yang tidak semua ulama sepakat menggu- 
nakannya, diantaranya ijma', qiyas, perkataan sahabat, istihsan, istihsab, maslahat musralah (istislah), 'urf, sadd zariah, dan syar'u man qablana.

Bentuk dari metode-metode di atas tidak bisa dilepaskan dari perkembangan hukum Islam yang telah berkembang kurang lebih 15 (lima belas) abad lamanya dengan proses sosial yang terjadi. Dinamisasi hukum Islam akan berpengaruh terhadap proses perkembangan maupun interaksi sosial. Begitu juga dengan status sosial, dikarenakan norma yang terserap dari hasil interaksi antara agama dengan masyarakat tersebut memunculkan implikasi terhadap proses sosial. Oleh karenanya penerapan hukum Islam sangat dipengaruhi oleh kondisi sosial masyarakat di mana hukum itu akan diterapkan.

Dinamika perkembangan hukum Islam diterapkan para ulama dengan menggunakan berbagai metode dan sumber dalil, diantaranya menggunakan istihsān dalam istinbat hukum, namun tidak semua sepakat menggunakan istihsan dalam berdalil dalam perumusan hukum Islam. Menarik untuk dikaji ketika terjadi ikhtilaf di kalangan Imam Mazhab berkaitan keeksisan istihsān tersebut dalam penggunaannya. Mazhab Hanafiyah dan Malikiyah menggunakan istihsān dalam istinbat hukum sebagai upaya mewujudkan tujuan syari' yaitu kemaslahatan. Namun disisi lain, madzhab Syafi'i dengan keras menentang istihsan sebagai salah satu metode dalam istinbath hukum.

Istihsan merupakan salah satu metode ijtihad yang diperselisihkan oleh para ulama, meskipun dalam kenyataannya, semua ulama menggunakannya secara praktis. Pada dasarnya, para ulama menggunakan istihsan dalam arti lughawi (bahasa), yaitu "berbuat sesuatu yang lebih baik". Tetapi dalam pengertian istilahnya, para ulama berbeda pendapat disebabkan oleh perbedaan dalam memahami dan mendefenisikan istihsan itu. Ulama yang menggunakan metode istihsan dalam berijtihad mendefinisikan istihsan dengan pengertian yang berbeda dengan definisi dari orang yang menolak cara istihsan. Demikian juga dengan ulama yang menolak penggunaan istihsan mendefinisikan istihsan dengan pengertian tidak seperti yang didefiniskan pihak yang menggunakannya. Seandainya mereka sepakat mengartikan istihsan 
itu, maka mereka tidak akan berbeda pendapat dalam menggunakannya sebagai suatu metode ijtihad. ${ }^{14}$

استحسن Istihsan secara etimologi berasal dari bahasa Arab, yaitu yang berarti memperhitungkan dan meyakini sesuatu itu baik, ${ }^{15}$ atau mengikuti sesuatu yang baik menurut perasaan dan fikiran. ${ }^{16}$ Makna yang hampir sama juga dipakai oleh Al-Sarakhsi, yaitu:

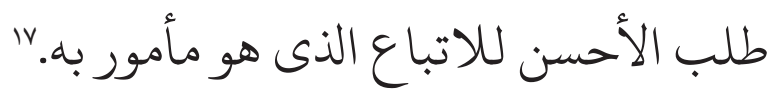

"Berusaha mendapatkan yang terbaik untuk diikuti bagi suatu masalah yang diperhitungkan untuk dilaksanakan."

Dari arti etimologi ini terlihat adanya seseorang yang menghadapi dua hal yang keduanya baik. Namun ada hal yang mendorongnya untuk meninggalkan satu di antaranya dan menetapkan untuk mengambil yang satunya lagi, karena itulah yang dianggapnya lebih baik untuk diamalkan.

Ulama Ushul Hanafiyah mendefinisikan istihsan dalam dua rumusan:

a) العمل بالاجتهاد وغالب الرأي فى تقدير ما جعله الشرع موكولا إلى آرائنا

"Berijtihad dengan segenap fikiran dalam menentukan sesuatu yang oleh syari'at menyerahkannya kepada pendapat kita."

b)

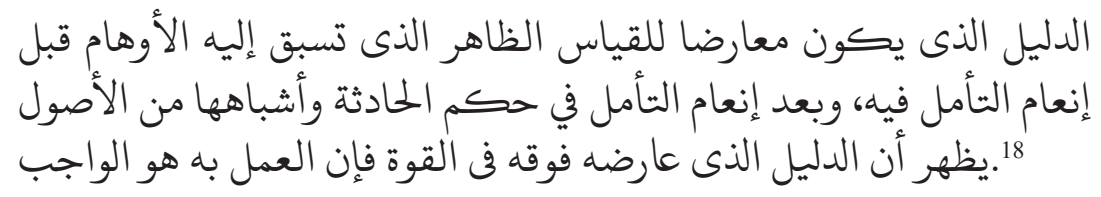

${ }^{14}$ Amir Syarifuddin, Ushul Fiqh, (Ciputat: PT. Logos Wacana Ilmu)., hlm. 304.

${ }^{15}$ Wahbah Al-Zuhaili, Ushul al-Fiqh al-Islami, (Damaskus: Dar al-Fikr Jilid. II, 2006)., hlm. 18.

16 'Abdul Wahhab Khallaf, mashaadir at-Tayri' al-Ilami fi ma la nassha fih, (Kuwait, Dar al-Qalam, 1972)., hlm. 69.

${ }^{17}$ Al-Sarakhsi, Ushul al-Sarakhsi, ditahqiq oleh Abu al-Wafa al-Afghani, (Beyrut: Dar al-Kutub al-'Ilmiyyah, 2005),, hlm. 200.

${ }^{18}$ Al-Sarakhsi, Ushul al-Sarakhsi, hlm. 200. 
"Dalil yang menyalahi qiyas yang zahir yang didahului dengan prasangka sebelum diadakan pendalaman terhadap dalil itu, setelah diadakan penelitian yang mendalam terhadap dalil itu dalam hukum yang berlaku dan dasar-dasar yang sama dengan itu ternyata dalil yang menyalahi qiyas zahir itu justru lebih kuat dan oleh karenanya wajib diamalkan."

Al-Karkhi sendiri (seorang pengikut mazhab Hanafi) mendefinisikan istihsan sebagai:

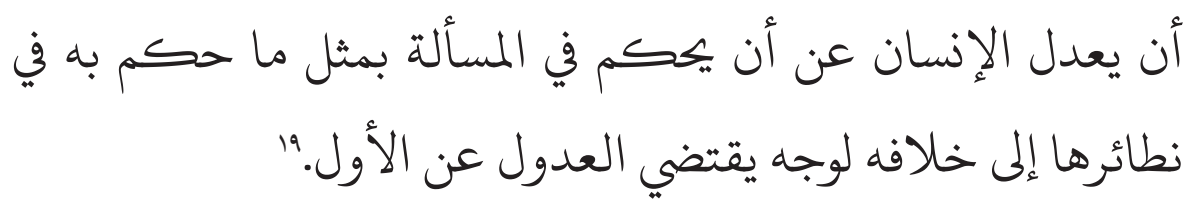

"Berpindahnya manusia (mujtahid) dalam menetapkan hukum terhadap satu masalah dari hukum yang sebanding dengannya kepada hukum lain karena ada alasan yang lebih kuat menghendaki perpindahan dari hukum awal tersebut."

Al-Sarakhsi sendiri merumuskan istihsan itu paling tidak mencakup empat hal:

1) ترك القياس والأخذ بما هو أوفق للناس (meninggalkan qiyas dan mengambil hukum yang lebih sesuai dengan manusia)

2) لب السهولة في الأحكام فيما يبتلى فيه الخاص والعام (mencari kemudahan dalam hukum-hukum yang dihadapi orang banyak atau orang tertentu)

3) الأخذ بالسعة وابتغاء الدعة (mengambil keluasan dan mencari kelegaan)

4) الأخذ بالسماحة وابتغاء ما فيه الراحة (mengambil yang permisif dan memilih yang di dalamnya ada ketenangan).

Definisi istihsan pertama yang berlaku di kalangan ulama Hanafiyah di atas tidaklah menyalahi sesuatu apapun dan semua ulama sepakat

\footnotetext{
${ }^{19}$ Muhammad Abu Zahrah, Ushul al-Fiqh, (t.t, Dar al-Fikr al-‘Arabi, 1958), hlm.263.

${ }^{20}$ Al-Sarakhsi, Kitab Al-Mabsuuth, (Beirut: Dar al-Ma'arif, jilid. X, t.th)., hlm. 145.
} 
terhadapnya, karena pengertian "yang terbaik dalam hal ini adalah dia antara dua hal yang kita dapat menentukan pilihan, karena syara' telah memberikan hak pilih pada kita. Contohnya penetapan ukuran mut'ah (pemberian hadiah) dari suami yang menceraikan isterinya sebelum dicampuri dan sebelumnya belum ditetapkan maharnya. Memberikan mut'ah itu wajib, yang ukurannya menurut kemampuan suami dengan syarat harus sesuai dengan "kepatutan". Tentang ukuran patut itu sendiri diserahkan kepada apa yang lebih baik berdasarkan pendapat yang umum.

Dalam definisi kedua terkandung adanya pembenturan dalil dengan qiyas zahir. Semula ada prasangka lemah pada dalil itu karena belum diadakan penelitian yang mendalam, namun setelah diteliti secara mendalam ternyata dalil itu lebih kuat daripada qiyas. Dalam hal ini dipandang lebih baik menggunakan dalil itu daripada menggunakan qiyas yang menurut lahirnya kuat. Meninggalkan beramal dengan qiyas untuk mengamalkan dalil itu disebut "istihsan" menurut ulama Hanafiyah.

Sedangkan definisi yang dikemukakan oleh Al-Karkhi, pada dasarnya tidak jauh berbeda dari definisi yang kedua. Istihsan itu menurut Al-Karkhi adalah berpindahnya dari hukum awal kepada hukum yang lebih kuat, kekuatannya itu adalah karena "dalil” bukan karena hukumnya (بأن القوة لأدلة لا للأحككام).21

Adapun definisi yang dirumuskan oleh Al-Sarakhsi dapat disimpulkan bahwa istihsan itu pada hakikatnya dua buah qiyas, pertama qiyas jali yang lemah pengaruhnya ini disebut dengan qiyas yang sesungguhnya, kedua qiyas khafi (tersembunyi) namun pengaruhnya kuat, inilah yang disebut dengan istihsan, artinya qiyas yang diubah menjadi istihsan. Al-Sarakhsi mendefinisikan istihsan lebih memandang kepada tujuannya, yakni kemaslahatan dan kemudahan bagi manusia dalam menghadapi berbagai problem hidupnya.

\section{Macam-macam Istihsan}

Ulama Hanafiah membagi istihsan kepada 6 macam, yaitu:

${ }^{21}$ Syamsuddin Muhammad ibn Muflah Al-Muqdisi al-Hanbali, Ushul Fiqh, (Riyadh: Maktabah al-'Abikah, jilid. IV, 1999)., hlm. 1464. 
a. Istihsan bi al-Nash, الإستحصان بالنص, (istihsan berdasarkan ayat atau hadits). Maksudnya ada ayat atau hadits tentang hukum suatu kasus yang berbeda dengan ketentuan kaidah umum. Misalnya dalam masalah wasiat. Menurut ketentuan umum atau qiyas, wasiat itu tidak boleh, karena sifat pemindahan hak milik kepada orang yang berwasiat dilakukan ketika orang yang berwasiat tidak cakap lagi, yaitu setelah wafat. Tetapi kaidah umum dikecualikan melalui firman Allah surat an-Nisa, setelah mengeluarkan wasiat yang ia buat atau hutang”. Berdasarkan ayat ini maka kaidah umum tidak berlaku untuk masalah wasiat

b. Istihsan bi al-Ijma', (Istihsan yang didasarkan kepada ijma'). Misalnya dalam kasus pemandian umum, Menurut ketentuan kaidah umum, jasa pemandian umum itu harus jelas, yaitu berapa lama seseorang mandi dan berapa jumlah air yang ia pakai. Akan tetapi hal ini akan menyulitkan bagi orang banyak. Oleh sebab itu para ulama sepakat menyatakan bahwa boleh mempergunakan jasa pemandian umum, sekalipun tanpa menentukan jumlah air dan lama waktu yang terpakai.

c. Istihsan bi al-qiyas al-khafiy, (istihsan berdasarkan qiyas yang tersembunyi). Misalnya, menurut ketentuan qiyas jaliy, (qiyas yang nyata), wakaf ini sama dengan jual beli, karena pemiliki lahan tersebut telah menggugurkan hak miliknya dengan memindahtangankan lahan tersebut. Oleh sebab itu hak orang lain untuk melewati tanah tersebut atau hak orang lain untuk mengalirkan air ke lahan pertaniannya melalui tanah tersebut, tidak termasuk dalam akad wakaf itu, kecuali jika dinyatakan dalam akad. Menurut qiyas al-khafiy, (qiyas yang tersembunyi), wakaf itu sama dengan sewa menyewa, karena maksud dari wakaf adalah memanfaatkan lahan pertanian yang diwakafkan, dengan sifat ini, maka seluruh hak orang lain yang telah ada di lahan pertanian tersebut seperti hak melewati lahan pertanian, termasuk ke dalam akad wakaf, sekalipun tidak dijelaskan dalam akad. Apabila seorang mujtahid mengambil hukum kedua (qiyas alkhafiy), makaa ia disebut berdalil dengan istihsan. 
d. Istihsan al-Maslahah, (Istihsan berdasarkan kemaslahatan). Misalnya ketentuan umum menetapkan bahwa buruh di suatu pabrik tidak bertanggungjawab atas kerusakan hasil komoditi yang diproduksi oleh pabrik tersebut, kecuali atas kelalaian dana kesengajaan mereka, karena mereka hanya sebagai buruh yang menerima upah. Akan tetapi demi kemaslahatan dalam memelihara harta orang lain dari sikap tidak bertanggungjawab para buruh dan sulitnya mempercayai sebagaian pekerja pabrik dalam mamsalah keamanan produk, maka ulama Hanafi menggunakan istihsan dengan menyatakan bahwa buruh harus bertanggung-jawab atas kerusakan setiap produk itu, baik sengaja atau tidak.

e. Istihsan bi al- "urfi, (istihsan berdasarkan adat kebiasaan yang berlaku umum). Contohnya seperti kasus pemandian umum serta di atas yang tidak bisa ditentukan berapa lama dan jumlah air yang terpakai, karena adat kebiasaan setempat bisa dijadikan ukuran dalam menentukan lama dan jumlah air yang terpakai.

f. Istihsan bi al-Dharurah, (Istihsan berdasarkan keadaan dharurat), Misalnya, sumur yang kemasukan najis, akan sulit untuk membersihkan sumur itu dengan mengeluarkan semua airnya, karena sumur itulah sumber mata airnya. Maka menurut mazhab Hanafi, cara membersihkan sumur itu cukup dengan memasukkan beberapa galon air ke dalamnya, karena keadaan darurat menghendaki agar orang tidak mendapat kesulitan dalam mendapatkan air untuk beribadah dan kebutuhan hidupnya.

\section{Kehujjahan Istihsan}

Sebagian ulama yang menggunakan metode istihsān sebagai landasan yang digunakan untuk mengistinbat suatu hukum, tentu tidak serta merta membuat atau mengadakan metode tersebut, pasti ada dalil yang digunakan sebagai dasarnya. Ahmad Sarwat dalam bukunya Seri Fikih Kehidupan menyebutkan ada beberapa ayat Alquran yang digunakan sebagai dasar istihsan. ${ }^{22}$ Beberapa ayat tersebut di antaranya adalah surah az-Zumar ayat 55 sebagai berikut:

${ }^{22}$ Ahmad, Sarwat, Seri fiqih Kehidupan, (Jakarta: Rumah Fiqih Publishing, 2002, Cet.II)., hlm. 145. 


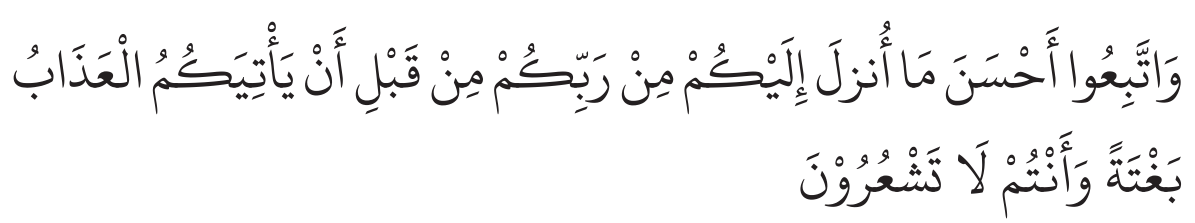

Artinya "Dan ikutilah sebaik-baik apa yang telah diturunkan kepadamu dari Tuhanmu sebelum datang azab kepadamu dengan tiba-tiba, sedang kamu tidak menyadarinya."

Dijelaskan dalam Tafsir Al-Muyassar bahwa ikutilah al-Qur'an, halalkanlah apa yang dihalalkan dalam al-Qur'an dan haramkan apa yang diharamkannya, dan laksanakanlah ketaatannya dan jauhilah kemaksiatannya, sebab segala yang ada dalam al-Qur'an mengandung kebaikan. Pendapat lain mengatakan bahwa yang dimaksud dengan sebaik-baik dari al-Qur'an yakni ayat-ayat muhkamatnya, bukan ayatayat mutasyabihat. Pendapat lain mengatakan yang dimaksud dengan itu adalah dengan memaafkan kesalahan orang lain tanpa menuntut balas, sebab menuntut balas dibolehkan dan memaafkan juga dibolehkan, namun ayat ini mendorong untuk memaafkan. Hal ini berlaku juga dalam segala hal yang memiliki dua sisi yang dibolehkan namun salah satunya lebih baik, baik itu dalam hal ibadah maupun lainnya. ${ }^{r}$

Menurut ulama yang menggunakan istihsan dalam ayat ini Allah memerintahkan kita untuk mengikuti yang terbaik, dan perintah menunjukkan bahwa ia adalah wajib. Di sini tidak ada hal lain yang memalingkan perintah ini dari hukum wajib. Maka ini menunjukkan bahwa istihsjn dapat dijadikan hujjah.

Ulama Hanafiyah menerima istihsan sebagai dalil yang kuat dalam menetapkan hukum syara'. Alasannya yaitu:

a. Ayat-ayat yang mengacu kepada mengangkatkan kesulitan dan kesempitan dari umat manusia, yaitu firman Allah dalam surat al-Baqarah:185, يريدالله يكم اليسرى ولايرد بكم العسر "Allah menghendaki kemudahan bagi kamu dan tidak menghendaki kesukaran .."

${ }^{23}$ Aidh al-Qarni, Tafsir al-Muyassar, (Jakarta, Qisthi Press, 2007)., hlm. 1316. 
b. Rasulullah dalam riwayat 'Abdullah Ibn Mas'ud, mengatakan : "Sesuatu yang dipandang baik oleh umat Islam, maka di hadapan Allah juga baik.." (HR Ahmad bin Hanbal)

c. Kadangkala memberlakukan hukum sesuai dengan kaidah umum dan qiyas adakalanya membawa kesulitan bagi umat manusia, sedangkan syari'at Islam ditujukan untuk menghasilkan dan mencapai kemaslahatan manusia. Oleh karena itu, seorang mujtahid boleh berpaling kepada kaidah lain yang akan memberinya hukum yang lebih sesuai dengan kemaslahatan manusia.

Pengalaman praktis misalnya, Istihsan dengan sunnah Rasul adalah dalam kasus orang yang makan minum karena lupa ketika ia sedang puasa, menurut kaidah umum (qiyas), puasa orang ini batal karena telah memasukkan sesuatu ke dalam badan dan tidak menahan puasanya sampai berbuka, akan tetapi hukum ini dikecualikan oleh hadits من أكل أو شرب ناسيا فلا يفطر فإنما,Rasulullah SAW yang mengatakan

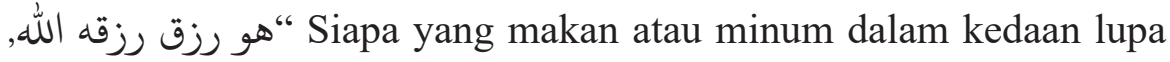
maka tidak batal puasanya, karena ini merupakan rizki yang diturunkan Allah kepadanya".

Sekalipun konsep istihsan yang pertama kali dikemukakan oleh Imam Hanafi kurang rinci dan tidak jelas sehingga mendapat tanggapan keras dari Imam Syafi'i yang menganggap bahwa istihsan itu membuat syara' sendiri, namun konsep istihsan oleh murid-murid dan pengikut Imam Abu Hanifah lebih disempurnakan, diperjelas dan dirinci secara sistematis sehingga konsep istihsan menjadi sempurna. Kemudian konsep ini diikuti oleh ulama-ulama Malikiyah dan sebagian ulama Hanabilah.

Menurut lisan ahli fikih terbagi dua macam: Pertama: Beramal dengan ijtihad dan pendapat yang telah lazim pada ketentuan atas apa yang dijadikan syara' sebagai wakil pada pendapat kita seperti pembayaran mut'ah yang disebutkan, seperti firman Allah QS AlBaqarah ayat $r$ r :

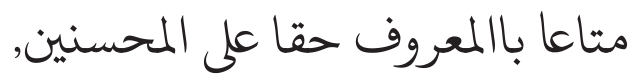


“...(bayarlah) mut'ah itu dengan ma'ruf, (sesuai kepatutan), yang demikian itu ketentuan bagi orang-orang yang berbuat kebajikan..."

Pada ayat ini jumlah (pembayaran mut'ahnya) dipermudah dan dilapangkan, dengan syarat dibayarkan dengan ketentuan yang patut. Kedua: Dalil yang ada perpalingan bagi qiyas zahir yang didahului keraguan sebelum dilakukan penelitian, namun setelah dilakukan penelitian pada hukum yang baru dan keserupaannya dari ushul memunculkan istihsan untuk membedakan antara bentuk ini dari dalil.

Berkata Radhiallu'anhu, istihsan qiyas disisi kita ada dua macam, Pertama: diamalkan istihsan dan ditinggalkan qiyas. Inilah yang merupakan hujjah syar'iy nya, sebagaimana firman Allah QS Az-Zumar ayat 17-18: فيشرعبادى الذين يستمعون القول فيتبعون أحسنه Maka berikanlah kabar gembira kepada hambaku yang menuruti perkataanku, lalu mengikuti apa yang paling baik diantaranya.."

Kedua berpendapat, diamalkan qiyas karena istihsan tidak bisa dijadikan hujjah, karena istihsan mengikuti hawa nafsu, menghendaki meninggalkan qiyas sedangkan qiyas merupakan hujjah, jika meninggalkan qiyas itu adalah batal.Maka yang shahih adalah meninggalkan qiyas pada suatu tempat dan beramal dengan istihsan.

\section{Simpulan}

Istihsan dapat di jadikan sebagai dalil syara' karena istihsan itu bukan menetapkan hukum dengan ra' yi semata, istihsan itu merupakan suatu cara istinbath hukum yang dapat di pertanggung jawabkan karena di dasarkan kepada sandaran (sanad) yang kuat.

Setelah diuraikan istihsan dalam ushul fiqih dalam pandangan madzhab Hanafi maka dapat dikatakan bahwa pada hakikatnya istihsan itu merupakan salah satu upaya mujtahid untuk mencari jalan keluar dari kekuatan kaidah umum atau qiyas terhadap suatu masalah juz'i dalam rangka mencari ketentuan hukum yang lebih sesuai dengan jiwa dan ruh syari'at, karena memang nash tidak bisa di pahami hanya secara bahasa semata tetapi harus di pahami dengan menggunakan logika pembuatan syariat (Al-Mantiq Al-tasyri'i) yang luas yang memberikan kesempatan 
kepada mujtahid untuk merealisasikan kehendak Al syari' semaksimal mungkin.

Syarakhsi telah menguraikan bahwa istihsan merupakan salah satu metode dalam berijtihad karena istihsan merupakan salah satu cara untuk menemukan jalan keluar atas problematika yang tidak terselesaikan oleh kaidah-kaidah umum dalam fiqh dengan berpaling pada kaidahkaidah tertentu. Pengembangan dan pembaharuan hukum Islam juga bisa dijelaskan dengan mengetahui tujuan utama ditetapkannya syari'at bagi manusia, yaitu untuk mencapai kemaslahatan manusia baik untuk saat ini ataupun dimasa yang akan datanag, serta untuk menghilangkan kerusakan. Dalam kajian usul fiqh tujuan ditetapkannya hukum Islam dikenal dengan maqasid asy-syari'ah, dan maqasid asy-syari'ah itu sendiri adalah memelihara al-mabadi' al-khamsah atau yang juga dikenal dengan istilah al-kulliyyat al-khamsah, atau ad-daruriyyat al-khamsah; yaitu menjaga agama, jiwa, keturunan, akal, dan harta.

\section{Daitar Pustaka}

Abdurrahman Wahid, Universalisme Islam dan Kosmopolitanisme Peradaban Islam, dalam "Kontekstualisasi Doktrin Islam dalam Sejarah”. Editor: Budhy Munawwar Rahman, Yayasan Paramadina, Jakarta, 1994.

Al-Gazali, Abu Hamid Muhammad bin Muhammad, Mustasyfa min 'Ilm al Ushul, Cairo, al-Matba'a al-Amiriyya, 1906.

Al-Hanbali, Syamsuddin Muhammad ibn Muflah Al-Muqdisi, Ushul Fiqh, Jilid. IV, Maktabah al- 'Abikah, Riyadh, 1999.

Al-Maragi, Abdullah Musthafa, Pakar-Pakar Fiqh Sepanjang Sejarah, LKPSM, Yogyakarta, 2001.

Al-Sarakhsi, Muhammad bin Ahmad bin Abi Sahl, Tarjamah al Mu'allif al Mabsuth, Juz 31, Dar al Kutub al-Ilmiah, Beirut. , Ushul al-Sarakhsi, Dar al-Kutub al-'Ilmiyyah, Beirut, 2005. , t.th., Kitab Al-Mabsuuth, jilid. X, Dar al-Ma'arif, Beirut. 
, Tarjamah al Mu'allif Ushul al Sarakhsi, Juz 1, Dar al Kutub al-Ilmiah, Beirut, 1993.

Al-Zuhaili, Wahbah, Ushul al-Fiqh al-Islami, Jilid II, Dar al-Fikr, Damaskus, 2006.

Al-Qardhawy, Yusuf, Pengantar Kajian Islam; Studi Analitik Komprehensif tentang Pilar-pilar Subtansi, Karakteristik, Tujuan, dan Sumber Acuan Islam, Pustaka Al-Kausar, Jakarta, 1999. , Al-khashaish Al-'Aamiyah al-Islam, Beirut-Libanon, 1993. , Madkhal li al-Dirasat al-Islamiyah, Beirut-Libanon, 1993.

Al-Qarni, Aidh, Tafsir al-Muyassar, Qisthi Press, Jakarta, 2007.

Hallaq, Wael B., Sejarah Teori Hukum Islam; Pengantar untuk Ushul Fiqh Mazhab Sunni, Rajawali Pers, Jakarta, 2001.

https://media.isnet.org/kmi/islam/gapai/Akulturasi.html, diakses pada 13 September 2020.

Khallaf, Abdul Wahhab, Mashaadir at-Tayri'al-Ilami fi ma la Nassha fih, Dar al-Qalam, Kuwait, 1972.

Sarwat, Ahmad, Seri fiqih Kehidupan, Rumah Fiqih Publishing, Cet.II, Jakarta, 2002.

Syafe'i, Rachmat, Ilmu Ushul Fiqh untuk UIN, STAIN, PTAIS, Pustaka Setia, Bandung, 2010.

Syarifuddin, Amir, Ushul Fiqh, PT. Logos Wacana Ilmu, Ciputat, 1999. Zahrah, Muhammad Abu, Ushul al-Fiqh, t.t, Dar al-Fikr al-'Arabi, 1958. Zysow, Aron, The Economy of Certainty: An Introduction to the Typology of Islamic Legal Theory, United State, Disertasi Ph.D. Harvard University, US, 1984. 